\title{
PRESERVING THE TINGUIAN CULTURAL HERITAGE: MOTHER TONGUE-BASED MULTI-LINGUAL EDUCATION AS TOOL
}

\author{
Elizabeth Valera ${ }^{1}$, Red Marian Antonette Valera ${ }^{2}$ \\ ${ }^{1}$ Human Resource Office, Divine Word College of Bangued \\ Bangued, Abra 2800, Philippines \\ bethvalera04@yahoo.com \\ ${ }^{2}$ Department of Social Sciences and Philosophy, Trinity University of Asia \\ Cathedral Heights, 275 E. Rodriguez Sr. Ave., Quezon City, Philippines \\ redmarian@yahoo.com
}

\begin{abstract}
Cultural heritage is important to people's identity and character.Preserving the culture is therefore very important for the future generations. The Tinguians who are the natives of Abra Province have their own culture which is distinct from other Filipino ethnolinguistic groups. Studies on the Tinguians however, show that many of their customs, traditions, practices and beliefs are no longer observed or done. To develop socio-cultural awarenesswhich enhances the pride of the learner's heritage, language and culture,the Department of Education has institutionalized the Mother Tongue-Based Multilingual Education as its fundamental educational policy and program. This study which is a qualitative research aimed to determine how the program helps in the preservation of the Tinguian culture. The interview guide was used to gather data from the teachers, and officials of the selected public schools in Tinguian communities where the program was piloted.These were complemented by the observations of the researchers when they visited the schools. Based on the findings of the study, the first language or mother tongue of the learners is Ilocano thus the medium of instruction for kindergarten to Grade 3 is Ilocano; some of the teachers are not Tinguians and cannot speak the dialect; there is no working orthography of the Tinguian dialects; there are no available teachers guide, reading and instructional materialsin Tinguian; many of the learners whose parents are Tinguians speak Ilocano with their friends and classmates.
\end{abstract}

Keywords: Preserving cultural heritage; Tinguian; Ilocano; First Language; Mother Tongue-Based Multi- lingual Education

\section{Introduction}

Cultural heritage is unique, precious and irreplaceable. It expresses the people's identity and character. The culture of a society or a nation is one thing that distinguishes it from the rest of the world. The colorful and lively Philippine culture for example, makes its people, distinctly Filipino. Culture is inextricable to specific geographical location thus people of different communities or nations differ because of their culture. Different cultural communities have their own distinctive ways of expressing their sense of self and wellbeing. The way they define the self and wellbeing is contingent on their culture.

For a society or people to know their identity, they should know their roots or origin. It is important for them to know the culture of the community or place where they come from. In the case of the Tinguians, they cannot claim that they are Tinguians if they are ignorant of the Tinguian culture. This is true to any society or group of people. 
Cultural heritage includes cultural properties such as buildings, monuments, artifacts, historic places, books, artworks, clothing and other objects with historical values. It includes intangible culture like social values, customs, traditions, practices, beliefs, artistic expressions and languages. It also includes natural heritage which are the biodiversity and geodiversity of a community or place. These are shared by the people overtime and transmitted by various means through generations.

\subsection{Background of the Study}

The culture of a people is very important. It is their culture that shows their values, beliefs and aspirations. It is their connection to the past. To know oneself, one must know his or her past. Knowing the past would make the present generation proud of their race. For the future generations to be able to appreciate who they are it is necessary for them to know their origin. There should be a way for them to know their past and to continue doing or observing the good practices of their great-great grandparents.

The Tinguians have a very rich culture. However, studies show that many of their customary and traditional practices are no longer observed or done. Their dialects are being endangered because they are seldom or no longer spoken by the young Tinguians. How can this beautiful culture be saved? A culture is difficult if not impossible to preserve if it is not done or observed. It should be made a part of the daily life of the people. How can this be done? How can this beautiful inheritance from the past be maintained in the present and bestowed for the benefit of future generations?

\section{1.a. The Tinguians}

The natives of the province of Abra in the Philippines are the Tinguians who are also called Itneg. The word Tinguian is derived from the word "tingue" which the Spaniards referred to mountain dwellers. Itneg means heathen or pagan. Although the Tinguians have already been
Christianized, they still call themselves Itneg.

There are two ways by which the Tinguians are classified. First is by geographical location: the mountain or upland Tinguians, and the valley or lowland Tinguians. The second classification is by ethno-linguistic grouping where there are 11 groups: Inlaud, Adasen, Maeng, Masadiit, Banao, Binongan, Mabaka, Gabang, Balatok, Belwang and Muyadan. Most of the valley Tinguians areInlaud. Some are Muyadan andMaeng. Although they are all Tinguians, they may not understand each other using their own dialect. A Binongan can scarcely understand a Maeng or Masadiit. The same is true with an Inlaud to an Adasen. Most of them however, understand and can speak Ilocano, so when they communicate, they use Ilocano. Thus, the linguafranca of the province is Ilocano.

Although the Tinguians occupy 19 of the 27 towns of the province, they are the minority. Their number is decreasing. The population of the Tinguians in the 1800s in proportion to the total population of the province was about $80 \%$; in the 1900 s, it dropped to about 50\%; and by 1948 , it was about $25 \%$. They are being absorbed by the Ilocanos (Schmitz, 1964). Majority of the population are the Ilocanos who migrated to Abra from nearby provinces such as Ilocos Sur and Ilocos Norte, and the Christianized Tinguians who have become Ilocanos. Many of the Ilocano towns today were Christianized Tinguian settlements. The latest statistical data available from the National Statistics Authority however, shows that the population of the Tinguians in proportion to the total population of the province had increased to $29 \%$ as of 2010 .

Table 1. Population of the Tinguians, 2010

\begin{tabular}{cc} 
Ethno-linguistic Groups & Population \\
\hline Adasen & 8,047 \\
\hline Balatok & 1,899 \\
\hline Banao & 2,107 \\
\hline Binongan & 4,912 \\
\hline Inlaud/Illaud & 898 \\
\hline Mabaka & 3,131 \\
\hline Maeng & 13,993 \\
\hline Masadiit & 8,559
\end{tabular}




\begin{tabular}{cc} 
Ethno-linguistic Groups & Population \\
\hline Muyadan & 3,357 \\
\hline Other Tinguians & 22,934 \\
\hline Total & $\mathbf{6 9 , 8 3 7}$
\end{tabular}

In 2010 the total population of the province was 234, 733. The Ilocano population in the same year was 155,237 and the Tinguians were 69,837 while other groups like the Tagalog, Pangasinanse, etc. were 9,659. In proportion to the total populations, the Tinguians were $29.75 \%$, an increase of $4.75 \%$ from the $25 \%$ in 1948; and in proportion to the Ilocanos, the Tinguians were $44.98 \%$. The population of the Ilocanos in proportion to the total population of the province was $66.93 \%$.

The lowland Tinguians have accommodated themselves very broadly with the Ilocanos. When they were compared to the Ilocanos, there was hardly any difference in physical appearance that can be noticed. They dressed like the Ilocanos. Their food They also have intermarried with them but at the start most Ilocanos did not approve of the marriage of their children to Tinguians, even when these belong to the propertied clans.

When the Spanish colonizers came to Abra some of the natives did not want them. They withdrew into the hinterland. These are now the mountain or upland Tinguians who are more conservative than the lowland Tinguians. They opposed Spanish rule and Christianity. They have preserved their individuality with amazing fidelity (Schmitz, 1964).

The early Tinguians were regarded as "wild" tribes and head-hunters. Today, however, head-hunting had stopped. Christianity, education and the institutionalization of government system are the reasons why this practice among the mountain Tinguians ended. The Tinguians of today are known to be peace loving people.

Even before the Tinguians embraced Christianity, they had their own religion. Although some writers like A. Perez, were of the opinion that the Tinguianscould not speak of any religion. However, Fay C.
Cole in his book, The Tinguian. Social, Religious and Economic Life of a PhilippineTribe concluded that religion plays an important role in the life of the Tinguians. They accept death with a belief in the afterlife. They believe in the good and bad anitos (spirits).Dr. Josef Schmitz, SVD in his book, The Abra Mission in Northern Luzon, Philippines wrote:

Their attitude and relation to the spirits (anitos) is the basis of a religious disposition that fills their entire life or at least influences it. All the customs that are observed when a house is built, when rice is planted or harvested, at a birth, a wedding, or at death, are supported and nourished by religious powers. It can be said that the pagan cult of the Tinguians is dictated by a belief in spirits which is handed on from generation to generation.

The Tinguians who are one of the indigenous peoples in the Philippines have their own customs, traditions, practices, beliefs, dialects or languages, music, songs and dances. These are distinct from those of other Filipino ethno-linguistic groups. Studies on the Tinguians however, show that many of their cultural practices and traditions are no longer observed or done. Almost all Tinguians are now Christians. Many of them have the wrong notion that the rituals and cultural practices of their forefathers are paganish which are against Christianity. They do not realize that culture and faith go together and complement each other; and that culture is the root of Christianity, and that it purifies culture. As pronounced by the Church, it is wrong for the missionaries to change the culture of the people whom they have converted to Christianity.

Very few, especially among the young Tinguians observe or perform their indigenous practices on birth such as the gipas or sikki; on courtship and marriage like the kalon, singlip, pakalon, tugtugaw or iyapdo; on death such as the inammaga, pinnayasyas, sinacsacopan, ing-ingalansinubsubalitan, pakpakada-palpalubos, and many more. Very few can dance the tadek or pallook, and sing thesalidummay, or do theuggayam. 
Today, there is only one dadaowacan or allopaganin the entire province who performs the dawak or allopagthus this ritual for curing the sick is now very seldom performed or done. Many of the young Tinguians seldom or no longer speak their dialect. They often speak in Ilocano and sometimes in Tagalog at home, in school or in their workplaces. The use of the Tinguian dialects is steadily declining. With the different changes in the environment like modern technology, physical changes in their communities, education and even Christianity, the Tinguians have changed a lot. They are now very different if compared to the early Tinguians. Their belief in the anitos and their religious rites are being forgotten. These are now becoming things of the past (Valera, Inlaud, My Mother Tongue is being Endangered).

\section{1b Preservation of Philippine Cultural Heritage}

To preserve the cultural heritage of a place or society, it is important to have the support of the government. The Philippines have several laws, statutes and programs for the preservation, protection and conservation of the national cultural heritage. The Philippine Constitution of 1987 which is the fundamental law of the land provides that "the State shall foster the preservation, enrichment and dynamic evolution of a Filipino national culture based on the principle of unity in diversity in a climate of free artistic and intellectual expression". The government recognizes that culture of a people makes them distinct from all other people. It sees the need for pursuing and developing national identity through knowledge and appreciation of the Filipino cultural heritage. The State is likewise mandated by the Constitution to conserve, develop, promote popularize and protect the nation's historical and cultural heritage. It further provides that the right of indigenous cultural communities to preserve and develop their culture and institutions.

Another law that was passed for the protection and conservation of the national cultural heritage is Republic Act No. 10066 which is the National Cultural Heritage Act of 2009. The law provides that "in the pursuit of cultural preservation as a strategy of maintaining Filipino identity it aims to: a) protect, preserve, conserve and promote the nation's cultural heritage, its property and histories, and the ethnicity of local communities; b) establish and strengthen cultural institutions; and c) protect cultural workers and ensure their professional development and wellbeing". It also provides that "the state shall endeavor to create a balanced atmosphere where the historic past coexists in harmony with modern society; that it shall approach the problem of conservation in an integrated and holistic manner, cutting across all relevant disciplines and technologies. It further provides that the State administers the heritage resources in a spirit of stewardship for the inspiration and benefit of the present and future generations". Government departments and agencies are also mandated for the preservation of the nation's cultural heritage. The Department of Education (DepEd) is mandated to formulate the cultural heritage education programs both for local and overseas Filipinos. Likewise, the Technical Education and Skills Development Authority (TESDA), Commission on Higher Education (CHED), and DepEd are mandated to set forth in their teaching programs the following cultural heritage education programs: a) protection, conservation and preservation of cultural heritage properties; b) instructional materials in print, film and broadcast media on the cultural and historical significance of cultural properties; and c)visitation, public accessibility and information dissemination on designated local cultural properties.

Republic 7356 , the law that created the National Commission for Culture and the Arts, emphasized the role of language in the promotion and development of Philippine culture and the art. Section of the law makes the Filipino citizen responsible for the preservation of the national historical heritage and its indigenous traditions. According to the 
law culture has three main elements. These are: a) the ideas, beliefs, attitudes of the people as national community, which include their scientific knowledge and beliefs; their religious beliefs; their myth, legends, folk literature, superstitions, riddles, proverbs and sayings, literature, philosophy and such others; b) Their norms or ways of doing, which include those as described by the Constitution; laws, rules and regulations, credo, customs, habits, rituals, ceremonies, and modes; and c) The material, or natural resources, flora and fauna, material wealth, infrastructures, technology, artifacts, works of art, and the like.

\section{1c Mother Tongue-Based Multi- Lingual Education}

The policy of the Philippine national government for the use of mother tongue in basic education helps in saving not only the different languages or dialects of the different ethno-linguistic groups in the country but their cultural heritage as well. The Department of Education issued Memorandum Order No. 74 which provides for the institutionalization of Mother Tongue-Based Multi-Lingual Education (MTB-MLE) in the Philippines. The program is implemented in two modes: first, as learning or subject area, and second, as medium of instruction. Mother Tongue as a subject area focuses on the development of beginning reading and fluency from Grades one to three. As medium of instruction, the learners' Mother Tongue is used in all domains or learning areas except Filipino and English subjects, from Kindergarten through Grade three.It aims to develop the following areas: a. Language development which establishes a strong education for success in school and for lifelong learning; b. cognitive development which focuses on Higher Order Thinking Skills (HOTS); c. academic development which prepares the learner to acquire mastery of competencies in each of the learning areas; and d. socio-cultural awareness which enhances the pride of the learner's heritage, language and culture.
The Kindergarten or Grade one class ideally is taught in the children's Mother Tongue. In schools where there are three or more Mother Tongues or variations of the eight major languages namely, Ilocano, Kapampangan, Cebuano, Tagalog, Pangasinanse, Bicolano, Hiligaynon and Waray; and four others which are: Tausog, Maguindanaoan, Maranao and Chabacano without an approved orthography spoken by the learners, the Lingua Franca of the place is used as medium of instruction. If there is an approved orthography of the Mother Tongue, and learning resources have been developed with trained teachers, the schools are encouraged to use the desired Mother Tongue (Guidelines on the Implementation of the Mother TongueBased Multi-Lingual Education, Enclosure to DepEd Order No. 16, s. 2012).

Mother Tongue, as defined by UNESCO, is the language one has learned first; identifies with or identified as a native speaker of by others; knows best; and uses most. It is the language that a person learned as a child at home which is spoken by the family, or whoever is taking care of him or her. The first language of the child is usually the language of his or her mother. It is a notion that the linguistic skills of a child are honed by his or her mother who takes care of him or her from birth until he or she can take care of himself or herself. In some East Asian countries, their mother tongue is their native or ethnic language. In Singapore, their mother tongue is the language of the ethnic group where they belong while their first language is English which is the nation's lingua franca.

A child who grows up in a home where the father and mother speak their own different languages may have two mother tongues. The same is true in communities where they have their own ethnic language but use another as official language. Bilingual or multi-lingual places may have more than one mother tongue.

1.1d Statement of the Problem 
The Mother Tongued-Based Multi-Lingual Education program of the Department of Education does not only aim for the learner's language, cognitive and academic development but it also aims to develop socio-cultural awareness which enhances the pride of the learner's heritage, language and culture. With the Mother Tongue of the pupil used as medium of instruction, and as a subject, the program can be a tool for the preservation of cultural heritage. The program has been piloted in elementary schools located in Tinguian communities.

This study aimed to determine how the program helps in the preservation of the Tinguian cultural heritage. The researchers were guided with the following questions:

1. What is the Mother Tongue or first language of the learners in the selected Tinguian schools?

2. What is the medium of instruction used in the selected Tinguian schools?

3. What are the learning resources available for the implementation of the Mother Tongue-Based Multi Education program?

4. What trainings on MTB-MLE have the teachers in the selected Tinguian schools participated in or attended?

5. What is the effect of the program on the preservation of the Tinguian cultural heritage?

6. What are the problems encountered by the teachers in the selected Tinguian schools in the implementation of MTB-MLE?

\section{Related Programs and Projects}

The two states in India which are Andhra Pradesh and Orissa implemented the Mother Tongue-Based Multi-Lingual Education on a pilot basis for tribal children. Andhra Pradesh started the program with eight tribal mother tongues while Orissa started with ten. Through these pilot studies they have seen that MTB-MLE is a critical input for the reduction of the number of school dropouts. It also increased the learning attainment levels of the children. They also concluded that the program is necessary for the development and revitalization of languages and for quality education especially of the minorities (Panda and Mohanty. Mother Tongue Based Multilingual Education Framework, Strategies and Implementation).

The MTB-MLE project that was done in Southern Thailand using the local language alongside Thai in primary schools had the following results: there was a decrease in the number of absentee- pupils; there was greater parental involvement in school activities; and test scores of the learners average at least 40 percent higher than pupils in other schools who were taught only in Thai. Significantly, the boys who were under the program were 123 percent more likely to pass the Thai language examination, and the girls were 155 percent more likely to achieve passing grade in Math ( http://www.bangkokpost.com/.../280767/t he-importance-of-a mother-tongue).

In the Philippines, several projects on the MTB-MLE have been implemented: A pilot project called the Lubuagan First Language Component Multi-Lingual Education was initiated through a partnership of educators from the Lubuagan community, the local government unit, the Department of Education and the Summer Institute of Linguistics, Inc. in 1998. Lubuagan is a town of Kalinga. It is a monolingual and almost homogenous community. Businessmen who come from other places but do business in the place use the ethnic language of Lubuagan which is the Lilubuagen. The people of Lubuagan who are called Lubuagen know how to speak Ilocano which is the regional language of wider communication, but only when they travel outside their place. Lilubuagen is the first language of the Lubuagen child and the only language that he or she speaks until he or she begins to go to school where he or starts learning the languages of education which are Filipino and English.

The program promoted the use of Lilubuagen. This complemented the 
ongoing education in Filipino and English which are the two major languages of education as required under the Bilingual Education Policy of the government. Grades one to three pupils of Lubuagan public schools were taught their subjects in Lilubuagen. They were also taught the same subjects using Filipino and English. The project was very successful. There was high level of participation among the pupils. They outperformed pupils from all other schools in the province by up to 30 percent for both Filipino and English in the 2006 National Achievement Test for Third Grade Reading. In 2007, they also had the best performancein all subjectswhich include Math, English and Filipino. Many parents were afraid their children would not learn English with the use of their mother tongue in their classes. They were proven wrong when their children learned faster and better by using their own language. Grade one pupils who were taught in their mother tongue could read quickly and fluently and have better comprehension than those who were taught to read only in Filipino and English.

Other programs and projects on the MTB-MLE were the First Language Component-Bridging Program that was implemented in Ifugao Province in 19861993, and the Culture Responsive Curriculum for Indigenous People-Third Elementary Education Project in 20032007, the Iloilo Experiments in 19481954 and 1961-1964, the Rizal Experiment in 1960-1966 and the Lingua Franca Project in 1999 to 2001. All of these programs projects show that when the language used and understood by the learners is used in teaching them, they can learn to read with understanding within the first few years of their schooling; they learn better in Math and Science; and their cognitive skills are improved. There are no dull moments in the classroom because the children participate more actively. They could express themselves easier and better. In addition, the pupils who have learned to read and write in their Mother Tongue, learned to speak, read and write easily and quickly in their second and third languages. They are also more competent in all their other subject areas than the pupils who did not start learning using their first language (Llaneta, 2010).

The experience of Tarik Solaiman Elementary School, a public school located at Barangay Sagrada Familia in Masantol, Pampanga, of using the language of the village which is Kapampangan, in teaching the children, was the same with the other schools that implemented the MTB-MLE. For the principal of the school, teaching in Kapampangan has been the best policy (Garbes, 2012).

The study entitled "Double Exposure in Mathematics: A Glimpse of MotherTongue First" that was conducted by DepEd Region IV-B has validated the fundamental observation that top performing countries in the Trends in International Mathematics and Science Studies are those that teach and test students in Science and Math in their own language.

(principal.blogspot.com/2011/01/multilin gual-education.html).

\section{Research Methodology}

The study is a qualitative research that made used of an interview guide to gather data from the teachers, and officials of the selected public schools in Tinguian communities where the Mother TongueBased Multi-Lingual Education program of the Department of Education was piloted. The data gathered through the interview were complemented by the observations of the researchers when they visited the schools. The conduct of the study was made easier because both researchers are from the province of Abra and because one of them is very familiar with the culture of Tinguians and could speak very well one of the Tinguian dialects which is Inlaud and could speak and understand the other Tinguian dialects, she being a Tinguian by blood and was born and grew up in her hometown which is a Tinguian community.

There were eight public schools in Tinguian communities in Abra where the 
program was piloted. The study covered four of the eight schools. Two schools are located in Inlaud communities; one in a Binongan place; and another in an Adasen village.

\section{Result and Discussion}

4.1 What is the first language of the learners in the selected Tinguian schools?

Most of the pupils in the Inlaud schools speak Ilocano. The Inlaud are valley Tinguians. The ealrly Inlaud were very much like the Ilocanos in physical appearance and the way they dressed. The same is very much true today. It is difficult to distinguish now an Inlaud from an Ilocano except in their dialect. Among the Tinguians they were the first to be baptized to Christianity. They lived and even at present their communities are near those of the Ilocanos. These may be some of the reasons why the pupils in the Inlaud schools speak Ilocano. In addition, some of them have Ilocano parent, either the father or mother is Ilocano. Intermarriage between Tinguians and Ilocanos is another reason for the Tinguians being "Ilocanized". Many of the Inlaud pupils can understand Inlaud but few can speak it. When the Inlaud researcher talked to them, and tried to question them many of them talked or answered in Ilocano. It was observed that they spoke Ilocano with their classmates inside and outside the classroom. According to the teacher-respondents, many of the parents of the children also speak Ilocano in their homes. It is their grandparents who speak Inlaud.

In the Binongan and Adasen schools almost all of the pupils speak the native language of the place. They also speak Ilocano but unlike the Inlaud children, they only speak Ilocano when somebody talks to them in Ilocano. The Binongan pupils talk to their classmates in Binongan, The same is true with the Adasen pupils. At home, most of them use their community dialect except few of them whose mother or father is not a native of or from the place. Most of the time however, they use Ilocano when they talk with their teachers in school. Outside the school, sometimes they talk to them in the dialect.

4.2 What is the medium of instruction used in the selected Tinguian schools?

In all the schools covered by the study, generally the medium of instruction is Ilocano, the lingua franca of the province of Abra In the second model of the use of the Mother Tongue as medium of instruction, as provided in the program, it is the lingua franca that is used as medium of instruction if there three or more Mother Tongues spoken by the pupils without an approved orthography. In the Inlaud schools however, there are two Mother Tongues of the pupils which are Ilocano and Inlaud. Some of the teachers sometimes use the dialect of the place in some of the subjects like Makabayan or Social Studies and in Math. The teachers said that it is difficult to use the dialect when they teach Science because they are afraid they might not be saying the correct translation in the dialect of the scientific terms. All of the teachers are from the place where they are teaching and can speak the dialect except one who is an Ilocano and can not speak but understand the dialect Inlaud.

4.3 What are the learning resources used by the teachers for the implementation of the Mother Tongue-Based Multi-Lingual Education program?

The teachers in all the four schools do not have books or reading material written in the dialect. There is no orthography of the three dialects. It is the Ilocano language which is used as medium of instruction that has orthography. There are Ilocano books and reading materials that are used by the teachers. They also have story books in Ilocano. The teachers who use the dialect of the place when they teach, which is very seldom, translate in the dialect the topics or lessons they take from books or learning material which are written in English, Filipino or Ilocano. One teacher tells stories that her 
grandmother used to tell her when she was a little girl, to her pupils. These are Aponibolinayen, the Story of Kanag, the Story of Dumalawi, How the Tinguian Learned to Plant, Sogsogot, and Dogedog. These Tinguian stories are featured in the book of Mabel Cook Cole titled "Philippine Folk Tales.

\subsection{What trainings on MTB-MLE have the teachers participated in or attended?}

There were several In-Service trainings on the MTB-MLE conducted in the division and in the region that the teachers have participated in. There were also some of them who have attended national seminar-workshops on the MTB-MLE program. They were one in saying however, that they have no trainings yet on the program where specifically the Tinguian dialects of Abra were considered and discussed as the Mother Tongue used in the implementation of the program.

4.5 What are the contributions of the MTB-MLE for the preservation of the Tinguian cultural heritage?

As of the present there is very little contribution of the MTB-MLE program for the preservation of the cultural heritage of the Tinguian.. There were 12 languages considered by DepEd in its MTB-MLE implementation, one of which is Iloko or Ilocano. There were also seven dialects that were added to the 12 major languages but not one of the 11 Tinguian dialects is among them. There are however 11 schools in the Division of Abra, eight of which are located in Tinguian communities, where the MTBMLE program has been piloted.

The creation of awareness among the officers, teachers, parents and pupils in the eight Tinguian schools of the importance of the Mother Tongue is yet perhaps the best contribution of the program as far as the Tinguians are concern. If the program is implemented in the different Tinguian schools replicating the experiences of the schools where it was piloted like the Lubuagan Experience where the teachers incorporated oral literature, local history, local arts, crafts and music in the curriculum to support the learners' home culture then the preservation of the Tinguian culture is assured. The use of the Mother Tongue in school helps in the preservation of the language or dialects especially in the Tinguian places where most of the young no longer speak or use their forefathers' dialect or language.

4.6 What are the problems encountered by the teachers in the implementation of the MTB-MLE program?

At first, the teachers did not know what dialect or language to use as medium of instruction. They were confused as to what language to use, whether the dialect of the place or Ilocano. In the Inlaud schools most of the teachers first tried to use Inlaud as medium of instruction but they stopped and switched to Ilocano when most of the pupils did not participate in class, and got low grades in their examinations.

The lack of references and instructional materials was the main problem encountered by the teachers. In the Binongan and Adasen schools. The community dialect is the mother tongue of almost all of the pupils of the school but the lack of learning materials in the dialect made the teachers use Ilocano. Ilocano books and other reading material are available because there are many Ilocano schools in the country especially in its northern part. Besides, in the 1950s to the 1960s the Ilocano language was used in schools in the province of Abra as medium of instruction. When one of the researchers of this study was in the elementary grades, in an Inlaud community, the medium of instruction then in Grades one and two was Ilocano. The books and other reading materials used were also in Ilocano. Using Ilocano as medium of instruction was easier for the teachers because of the availability of Ilocano teaching materials.

\section{Conclusions}


Based on the findings of the study, the following conclusions were drawn:

a. The Mother Tongue or language spoken and knows best by the Inlaud children is Ilocano, while those of the Binongan and Adasen schools are the dialects of their community- Binongan and Adasen;

b. The medium of instruction in the selected Tinguian schools is Ilocano, the language most of the pupils speak and where there are available learning and teaching materials;

c. The learning resources available for the MTB-MLE program are original, culturally relevant, and reflective of realities in Ilocano communities, which are written or expressed in Ilocano;

d. All of the teachers in the Tinguian schools where the MTB-MLE program was piloted had participated in or attended several trainings on the Mother tongue Based-Multi Lingual Education but they feel that these were not enough for them to be ready for the implementation of the program. They lack trainings using the dialect of the community and felt that they were not really ready to implement it;

e. Making the people in the community aware of the importance of the use of the mother tongue is the best contribution of the program. Full implementation of the MTBMLE in accordance to the plan of DepEd perhaps is needed to be able to attain its objectives, one of which is the preservation of cultural heritage; and

f. The lack of learning materials in the Tinguian dialects was the biggest problem encountered by teachers in the implementation of MTB-MLE. Another was their lack of training on the use of the native dialect of the community. They also had the dilemma of what dialect to use, whether the dialect of the community or the one spoken by the pupils.

\section{Recommendations}

It is hereby recommended that there should be more trainings of the teachers on the MTB-MLE to build their capacity to design and use native language materials and graded stories such as the development and production of Tinguian alphabet primers and books. Teachers who belong to the community, knows the culture of the people of the place and speaks the mother tongue of the pupils should be assigned to teach for the implementation of the program. Orthography of the mother tongue of the learners :should be established by experts of the language.. Learning materials on the mother tongue that are original, culturally relevant, and reflective of local realities should be developed and produced. There should be active participation of the local government official, residents of the localities, parents and pupils in the implementation of the program. In Tinguian places where the first language of the children is not the native language or dialect, it should be used or taught as second language.

\section{References}

[1] Cole, Fay Cooper, The Tinguian: Social, Religious, and Economic Life of a Philippine Tribe, Chicago: Field Museum of National History, 1922.

[2] DepEd Order Number 16. S. 2012, The Institutionalization of Mother Tongue-Based Multi Lingual Education. Flores, Gilbert, M., Rationale of Mother Tongue-Based Multi-Lingual Education, school.principal.blogspot.com/2011/ 01/multilingual-education.html (Retrieved on December 14, 20154).

[3] Guidelines on the Implementation of the Mother Tongue-Based MultiLingual Education, Enclosure to DepEd Order No. 16, s. 2012.

[4] Llaneta, Celeste Ann, Castillo, The Language of Learning: Mother Tongue-based Multilingual Education in the Philippines, The 
Forum, Volume II, Issue 2, MarchApril 2010.

[5] Pado, Felicitas, E., The Mother Tongue-Based Multi-Lingual Education in the K to 12 Program.

[6] Ceap.org.ph/upload/download/20136 /417420447_1.pdf. (Retrieved on 14, 2014).

[7] Panda, Minati and Mohanty, Ajit, Mother Tongue Based- MultiLingual Education: Framework, Strategies and Implementation

[8] (Concept Note for an International Meet and Strategy Dialogue). Republic Act Number 7356, An Act Creating the National Commission of Culture and the Arts.

[9] Republic Act Number 10066, The National Cultural Heritage Act of 2009. Schmitz, SVD, Josef, The Abra Mission in Northern Luzon, Philippines 1598-1955, Cebu City: San Carlos Publication, 1964. The Importance of the Mother Tongue, http://www.bangkokpost.com/.../280 767/the-importance-of-a mothertongue (Retrived on December 14, 2014).

[10] The Philippine Constitution of 1987, Article XIV, Sections 14-18. 